Rev. Tadeusz Zadykowicz John Paul II Catholic University of Lublin

\title{
Baptism as the Beginning of the Path to Moral Perfection in One's Personal and Social Life
}

The Christian moral life can be compared to a path marked out by particular stages. The beginning of this path is no less important than its end, which is perfection in the temporal dimension and salvation in the ultimate spiritual dimension. Contrary to popular opinion, the beginning of the path is not associated with an individual's personal desire to be perfect; rather, it is a gift from God, who accompanies man throughout his entire life and needs his free response. Among the many gifts that God imparts to man, man receives essential gifts in the sacrament of Baptism. These gifts constitute the subject of moral action itself; they interiorly form man without determining his actions absolutely or depriving him of his freedom. A "new," free, and responsible action, the fruit of which is man's perfection as an individual and as a member of a natural and supernatural society, flows from this interior transformation. The basic character of the gifts of the sacrament of Baptism is that they are the source itself of a specifically Christian morality and not just an ordinary aid in the moral life.

Key words: Baptism, sacraments, morality, moral perfection.

The Christian concept of the moral life differs from other concepts because not only are the particular norms and principles primarily important, but so too are how they came about. This concept does not negate completely the effort that man must make in order to subject his freedom to the commandments, but it first points out the deeper reasons why man should be obedient to them-motives that can be perceived in the gift of God, which is also the source from which these obligations arise. 
Moral Theology

The sacrament of Baptism is the moment when God bestows His gifts in a particular way. Along with the sacrament of Baptism, man receives the gift that St. Paul calls "newness of life" (see Rom 6:4), a "new self" (cf. Eph 4:24), and he becomes a "new creation" (cf. Gal 6:15, Rom 6:4, and 2 Cor 5:17). With this gift man accepts the obligation that can be succinctly described as "acting according to Baptism," or as "living in accordance with Baptism." All of Christian morality should be the fulfillment of these obligations that arise from the gift of God that man receives in this sacrament of vocation. ${ }^{1}$ In this way, one may look at Baptism as the beginning of the path that leads to both individual and social moral perfection. It is also the beginning of the process that enables man to live in union with Christ in the Church. ${ }^{2}$ For, as Pope Francis says, "We are, in fact Christians to the extent that we allow Jesus Christ to live in us" the life that He initiated and makes possible through the sacrament of Baptism. ${ }^{3}$

\section{The Essential Character of the Gifts of the Sacrament of Baptism}

By reflecting on Baptism, it is possible to discover the very essence of the moral life and then the concrete moral obligations that flow from this sacrament and that pertain equally to a person's individual sanctification and relationship with God as well as to communal life. ${ }^{4}$ The sacrament of Baptism ushers man into the fullness of life in Christ and the community of the Church. Baptism also strengthens man so that, thanks to grace, he can be a sure "sacrament of Christ in his life." 5 In this sense, Baptism is the beginning and the gateway because, by enabling man to participate in the death and resurrection of Christ, it also obliges him to participate actively in the life of the Church and in secular society, which ultimately orients him toward his individual and social perfection.

$1 \quad$ Cf. John Paul II, Post-Synodal Apostolic Exhortation Christifideles Laici, 10.

$2 \quad$ Cf. Franciszek, Katecheza Dzieci i znak krzyża [04.18.2018].

$3 \quad$ Cf. Franciszek, Katecheza Fundament życia chrześcijańskiego [04.11.2018].

4 The Church's current teaching often includes issues related the moral dimension of the sacrament of Baptism, which is the topic of many studies. Cf., for example, A. Niemira, "Moralny wymiar sakramentu chrztu w świetle encykliki Lumen fidei papieża Franciszka," Teologia i Człowiek 39(2017), no. 3: 11-23. I also took up this question in the previously published article T. Zadykowicz, “Chrystopraksyzm doktryny chrzcielnej," Teologia i Człowiek 3(2016): 55-76.

5 Cf. International Theological Commission, The Reciprocity between Faith and Sacraments in the Sacramental Economy (2020), 73. 
The morality toward which Baptism is oriented is the work of a subject who is interiorly transformed, endowed with new life, and created anew. According to this kind of morality, concrete acts are perceived as an exterior manifestation of the individual, as an exterior revelation of the richness of the gift that he has received in Baptism. Thus, what a Christian should do or how he should act arises from who he is, and who the Christian is and who he becomes through his actions have their origin in the sacrament of Baptism.

Baptism is what sets a Christian apart; Christian morality is specific because it stems from the fact that it is the work of a "new self" (cf. Eph 4:24), and a "new creation" (cf. Gal 6:15, Rom 6:4, and 2 Cor Moral $5: 17$ ) - it is the fruit and consequence of the gift of "new life" (cf. Rom 6:4), the work of those "called to be holy" (cf. Rom 1:7, 1 Cor 1:2; 2 Cor 1:1), "children of God" (cf. Phil 2:15), "baptized into Christ" (cf. Rom 6:3), "grown into union with Him" (cf. Rom 6:5), enlightened (cf. Eph 5:14), and "washed"(cf. Titus 3:5; 1 Cor 6:11). All of these expressions that St. Paul uses describe the state of a Christians after baptism.

Pauline terminology that describes a person after Baptism indicates the essential transformation that has taken place, the fruit of which should be proper [moral] behavior. This terminology also indicates the basic character of the gift. Baptism brings about a fundamental change in man's personality through which the "old man," who committed sin, is buried with Christ in order to rise with Him, meaning participate in His new life, glory, kingdom, and inheritance. ${ }^{6}$ At the same time, man receives the forgiveness of his sins by virtue of the merits of Christ's death. As a result, Baptism internally transforms man who has been called to enter into a covenant with God and leads him into a new sphere and dimension of life. ${ }^{7}$ Through Baptism, man receives the gift of new life and becomes like Christ; he, therefore, enters into a covenant, which means that his behavior also becomes "new."

The Christian morality that arises from Baptism should be distinguished by "newness." This means that the life of Christ that begins in man because of this sacrament and through the forgiveness of sins connected with it ushers man on the path of sanctification and salvation, which entails making specific moral choices. In turn, these choices bear the mark of Baptism and are man's response to the sacrament. In

$6 \quad$ Cf.K. Wasiutyńska, “Chrzestjako pierwotnakonsekracja.Uźródeł powszechnego powołania chrześcijan do świętości,” Teologia i Moralność 10(2015), no. 1: 8.

7 Cf. J. Ratzinger, “Chrzest jako początek i drogowskaz życia chrześcijańskiego,” in: J. Ratzinger. Opera omnia, vol. 8, part 2: Kościót-znak wśród narodów. Pisma eklezjologiczne i ekumeniczne, eds. K. Góźdź, M. Górecka, Lublin 2013, 1232. 
Moral Theology

this way, Baptism, which brings about a new creation and constitutes a new birth (cf. John 3:3-5), makes man capable of living a Christian life, a new life.

From the reception of the sacrament of Baptism arises the need for faith, which is not limited to the general acceptance of God's saving will, but also includes concrete decisions. This sacrament obliges man not only to direct his life in a general sense, but also to more and more intensively behave like Christ in every area of his life. He who experiences an interior transformation by participating in the paschal mystery of Christ is also called to give witness to the gift that he has received through a life of worship which leads not only to devotion but also involves the moral life.

The communion with God that begins through Baptism should be confirmed throughout a person's entire life and by following specific moral precepts. Behavior that is worthy of a Christian is, therefore, the consequence of the essential transformation that takes place during Baptism. Christian life can be compared to a path on which the gift of the Holy Spirit that began in Baptism unfolds gradually. The ultimate goal of this path is to give oneself completely to the Father according to Jesus' example. While this begins with a general orientation, it also involves many areas of temporal life.

\section{Baptism - the Foundation of Personal Sanctification}

St. Paul describes the essential gift of the sacrament of Baptism when he states: "we who were baptized into Christ Jesus were baptized into his death" (Rom 6:3). At the same time, the Apostle emphasizes: "so that, just as Christ was raised from the dead by the glory of the Father, we too might live in newness of life" (Rom 6:4). Firstly, this means that entrance into new life and the new covenant does not come about through the work of man; rather, it is a gift of grace. Therefore, it requires that the baptized respond through specific moral attitudes that, when realized, result in a new dignity, which is a gift, and finds its fulfillment in the baptized person's "newness" of the moral life. ${ }^{8}$

The gift of new life is, therefore, an obligation that arises from the sacrament of Baptism. The one who has died to sin (cf. Rom 6:2) is also called to constantly combat sin (cf. Rom 6:12-14). The one who is "baptized into Christ" (cf. Gal 3:27) must also continually "put on the Lord Jesus Christ" (cf. Rom 13:14), since he has already passed from

Cf. A. Olczyk, "Chrzest," in: Jan Paweł II, Encyklopedia nauczania moralnego, eds. J. Nagórny, K. Jeżyna, Radom 2005, 106. 
death to life (cf. Col 3:1-4) and is continually called to put to death within himself that which is contrary to new life (cf. Col 3:5-17).

Having received Baptism, man is first obliged to have an attitude of gratitude. Although gratitude is more clearly connected with the Eucharist, the sacrament of Baptism enables man to discern God's special love as well as His undeserved gift, which requires man's free response. To be baptized, say Ratzinger, means to be immersed in God's "Yes," which precedes man and sustains him. ${ }^{9}$ The essence of gratitude is to recognize this gift. This gratitude, which can be expressed in many ways, can be distilled to the joyful fulfillment of all of one's tasks and obligations with the inner conviction that this is the only proper response to God's anticipatory love. In this way, baptismal life primarily means subordinating one's life to grace. For, man lives because of grace, and the action of this grace is the norm of Christian existence. The essence of this existence is to cooperate with God-with His gift-which is not just an add-on to the moral life or something that serves only to enable one to follow the commandments. Rather, God Himself, who by bestowing, calls man to perfect himself and to build up the community.

By beginning a new life within the Christian, the sacrament of Baptism calls him to seek perfection. The fundamental moral call to lead a holy life is connected with Baptism. Of course, this perfection and holiness can be manifested in many different ways, but it consists firstly in man's constant battle against sin and everything that is an obstacle on the path to fullness of life in Christ (cf. Rom 6:1-14; Col 2:11-13). ${ }^{10}$ Since persisting in sin contradicts the fundamental principles of the Christian life, dying and rising with Christ in Baptism must entail renouncing egoism and one's sinful past.

The negative aspect of perfecting oneself must be balanced with more positive aspects-with the individual's maturation to an ever more perfect and complete love. For, new life must not only exclude remaining in mortal sin and giving into one's addictions and vices, but also entail the beginning of a new kind of existence that involves striving to offer oneself to God ever more completely (cf. 2 Cor 5:15; Rom 14:7-9; Gal 2:20). Entering into this life through Baptism expresses the paschal character of Christian existence and requires not only a single renunciation of the state of sin, but also a constant "exodus"

9 Cf. J. Ratzinger, "Chrzest jako początek i drogowskaz życia chrześcijańskiego," 1233.

10 Cf.Franciszek, Katecheza Chrzest daje sitę do walki [04.25.2018]; Ibid., Katecheza Wyrzeczenie się szatana i wyznanie wiary [05.02.2018]. 
Moral Theology

from the state of $\sin$ to the state of grace. In this way, the image [of God] that man has within himself from the moment of his creation is continuously unveiled and man's life thus shows forth his supernatural likeness to God.

During Baptism, man receives not only the animating and sanctifying grace of the Holy Spirit but also the baptismal seal known as the "mark" (sfragis in Greek) about which the Apostle Paul speaks: "you [Christians ...] were sealed with the promised holy Spirit" (Eph 1:13; cf. 4:30; 2 Cor 1:22). This mark is a sign of belonging. In ancient times, the presence of a seal on a slave, animal, or inanimate object indicated that it was a specific person's property. In a similar way, the baptized person becomes God and Christ's property (cf. Rev 7:1-8), and his essential and ultimate sanctity, which St. Paul calls "holy" (cf. Rom 1:7; 1 Cor 1:2; 2 Cor 1:1), is realized in this belonging. This sanctification is made indelible through a permanent mark. ${ }^{11}$

In Baptism, which expresses man's belonging to God, the promise that: "You will be to me a kingdom of priests, a holy nation" (Ex 19:6) is fulfilled in a new way. As a result, the sacrament of Baptism should be understood as the source of man's obligation to participate in the life of worship and in the remaining sacraments, which should subsequently enliven the realization of the Christian call to holiness. ${ }^{12}$ This priestly aspect of Baptism sheds light on the meaning of the passage in Paul's Letter to the Romans where he says that reception of this sacrament signifies personal union with Jesus' paschal mystery-the only priestly sacrifice that is truly perfect and pleasing to God (cf. Rom $6: 3-4)$. Because of this union, every baptized person becomes capable of making his entire life a priestly sacrifice that can be offered up with Christ's sacrifice (cf. Rom12:1; 1 Pet 2:4-5). John Paul II emphasizes: "It is necessary to joyfully discover this aspect of the mystery of 'new life' that begins through Baptism - the first sacramental source of the "universal priesthood' whose basic task is to offer worship to God!"13

The Christian belongs to Christ from the moment of Baptism onward. He should, therefore, lead a life worthy of this state (cf. Col $3: 5-17)$. The baptized person is called to holiness because he has been

11 Cf. Franciszek, Katecheza Znamię przynależności na zawsze [05.09.2018].

12 In this sense, since the Middle Ages baptism has been called the "gateway to the sacraments." Cf. Catechism of the Catholic Church, Poznań 1994, 1213; Code of Canon Law, Poznań 1984, Can. 849.

13 Cf. Jan Paweł II, Katecheza Chrzest w Kościele - wspólnocie kapłańskiej i sakramentalnej [03.25.1992], 6. Cf. also: J. Hadryś, "Udział ochrzczonych w kapłańskim, prorockim i królewskim posłannictwie Chrystusa," Teologia i Moralność 10(2015), no. 1: 30. 
sanctified in Jesus Christ (cf. 1 Cor 1:2). St. Paul describes this calling as participation in the sufferings of Christ (cf. 2 Cor 1:5; Col 1:24; cf. also: 1 Pet 4:13, 5:1). This means that the one who is baptized should lead the kind of life that Christ led and imitate Him (cf. Heb 12:1-3). As mentioned before, the realization of this vocation must involve a battle against sin but also-and more positively-becoming like Christ. Christ's true Sonship, meaning His submission to the Father in everything, should serve as an example of filial devotion. Baptism, which makes man a child of God, calls the baptized person to realize his sonship by imitating Christ perfect example in carrying out His Father's will (cf. John 8:28-29; Heb 10:5-7). Christ revealed this obedience most perfectly on the cross. For this reason, man's participation in Christ's death, which takes place in the sacrament of Baptism, should be expressed in man's giving himself to the Father and should be a part of the baptized person's entire life. The spirit of filial sonship to which this sacrament calls the baptized should also be expressed in an openness to God's gifts and trust in Him.

Baptism - to be "raised with Christ"-obliges man to orient himself toward heaven (cf. Col 3:1-4). The morality of Baptism is not, therefore, aimed only at achieving perfection in the temporal realm or at self-realization. The purpose of such morality is salvation. The purification from sin that takes place through Baptism and faith (cf. 2 Pet $1: 8-11 ; 1$ Pet $3: 21$ ) must be confirmed in man's sincere desire and effort to attaining eternal life. To realize a morality understood in this way means not only to combat sin but also to acquire virtue. Needless to say, many virtues are the fruit of the sacrament of Baptism. It seems, however, that all of them can be distilled down to faith, hope, and love because these three virtues express man's lifelong attitude and contain the rest of the virtues, even those that are indispensible for communal life to function properly.

Baptism and faith alone are not enough to attain salvation. It is also necessary to keep God's commandments. For this reason, in addition to conferring the sacrament of Baptism, apostolic mission includes teaching the faithful to observe everything that Jesus has commanded (cf. Mt 28:20). ${ }^{14}$ John the Baptist pointed to Christ not only because he baptized, but also because he emphatically reminded people of God's commandments. It is for this reason that Ratzinger says that to be baptized means to stand beneath the sign of God's commandments and to receive them as the grace of the good path that God has

14 Cf. Francisek, Katecheza Wychowanie chrześcijańskie jest prawem dzieci [05.16.2018]. 
given. ${ }^{15}$ These commandments concern attaining personal religious and spiritual perfection and interpersonal relationships.

\section{Baptism - the Foundation of Communal (Ecclesial) Life}

Baptism unites man with God the Father, Christ, and the Holy Spirit. A person who is united to the Man-God in this way-who has become a child of God - is also united with others - the children of God -who are likewise united with God Himself and, thus, constitute the community

Moral Theology of God's children: the new people of God known as the Church (cf. Gal 3:26-29). Thus, by bringing the children of God to life by uniting them with Jesus, Baptism also unites them with Christ's Body the Church. This means that every baptized person is a spiritual temple. In this way, this sacrament becomes every individual's participation in the Church. And, it is to the Church that Christ's spousal loves applies. The one who receives Baptism also participates in His love. ${ }^{16}$ He who is born again through Baptism does not remain alone; rather, he enters into the great family of the People of God, the Church. Therefore, Baptism brings man into not only a personal relationship with God but also a new relationship with others; it is to dwell and live in the company of the saints, in the universal Church. ${ }^{17}$

In addition to new life, freedom, and purification from sin, Baptism makes the soul holy as a new condition for belonging to God as St. Paul says in his First Letter to the Corinthians: "...but now you have had yourselves washed, you were sanctified, you were justified in the name of the Lord Jesus Christ and the Spirit of our God" (6:11). According to the Apostle Paul's teaching, the entire Church has been purified by Christ and "cleansed [...] by the bath of water with the word" (Eph 5:26). In Her members the Church becomes "holy and without blemish" (cf. Eph 5:27). The entire community benefits when its members receive Baptism, which frees them from their sins; for, this sacrament opens up the fixed path toward spiritual maturity (cf. Eph 2:10). Clearly, the ability and obligation for Christians-both individually and as an entire community - to live a holy life arises from the baptismal anointing. According to St. Paul, the baptized have "died

15 Cf. J. Ratzinger, "Chrzest jako początek i drogowskaz życia chrześcijańskiego,” 1235 .

16 Cf. Jan Paweł II, Katecheza Chrzest w Kościele - wspólnocie kapłańskieji sakramentalnej [03.25.1992], 7.

17 Cf. J. Ratzinger, "Chrzest jako początek i drogowskaz życia chrześcijańskiego," 1234. 
to sin" and should renounce a life of sin (cf. Rom 6:2). "Consequently, you too must think of yourselves as [being] dead to sin and living for God in Christ Jesus," says St. Paul (Rom 6:11). In this sense, Baptism causes the entire community to participate in the death and resurrection of Christ, in His victory over the forces of evil. ${ }^{18}$

The sacrament of Baptism lies at the source of ecclesial communion in holiness. John Paul II introduces this fact based on the passage from St. Paul: "[O]ne Lord, one faith, one Baptism" (Eph 4:5), which was quoted by the Second Vatican Council in reference to the common features that unite Christians in Christ and the Church. ${ }^{19}$ The ontological, ecclesiological, and ethical holiness of every believerwhether lay or religious-is integral to participation in the life of Christ through Baptism. ${ }^{20}$ "Incorporated in the Church through Baptism, the faithful are destined by the Baptismal character for the worship of the Christian religion; reborn as sons of God they must confess before men the faith which they have received from God through the Church." 21 The aforementioned passage echoes the words of St. Paul: "For in one Spirit we were all baptized into one body" (1 Cor 12:13). The acknowledgment that one is chosen by God without having any merits of his own and called to enjoy the dignity of being His child also means that the baptized person is called to have an apostolic attitude, to give witness to the faith, to increase the Church's holiness, and to sanctify the world. Desiring to show God his gratitude fully, the one who is baptized takes on the duty to announce to others the message of salvation (cf. 1 Pet 2:9). To be baptized means to enter into the life of the Church, to support Her with the help of others, and to allow Her to sustain us. ${ }^{22}$

Baptism reveals the communal dimension of the Christian life. The action of the Holy Spirit draws everyone into one Body of Christ. According to Christian morality, this means that Baptism calls teach person to seek and deepen unity. The gift of holy Baptism calls the

18 Cf. Jan Paweł II, Katecheza Chrzest w Kościele - wspólnocie kapłańskiej i sakramentalnej [03.25.1992], 4.

19 Cf. Second Vatican Council, Dogmatic Constitution on the Church Lumen Gentium, 32 .

20 Cf. ibid., 40. Cf. also: Jan Paweł II, Katecheza Powołanie świeckich do świętości [11.24.1993], 2.

21 Second Vatican Council, Dogmatic Constitution on the Church Lumen Gentium, 11.

22 Cf. J. Ratzinger, "Chrzest jako początek i drogowskaz życia chrześcijańskiego," 1234. 
Moral Theology

baptized to be responsible for the community of the Church and to accept the Church's teachings and Her authority with faith. Cooperation in the work of salvation is a sign of being responsible for the Church. Baptism is, thus, a call to brotherhood as well as an unceasing search for true unity. This unity, however, is ultimately based on a love that is expressed in many particular attitudes and behaviors. It means openness to others, bearing with their weaknesses, seeking that which serves the common good, and building up others (cf. Rom $15: 1-3$ ). Such love is not possible without sacrifice and patience (cf. Rom 15:5-6). Supernatural solidarity on the path to salvation has its source in the sacrament of Baptism. Solidarity among the baptized in daily matters also flows from this reality, since "If [one] part suffers, all the parts suffer with it; if one part is honored, all the parts share its joy" (1 Cor 12:26).

The source of unity, which is built up through concrete attitudes and actions, is supernatural. St. Paul speaks of this unity when he writes: "I [...] urge you to live [...] with all humility and gentleness, with patience, bearing with one another through love, striving to preserve the unity of the spirit through the bond of peace-one body and one Spirit, as you were also called to the one hope of your call; one Lord, one faith, one Baptism; one God and Father of all, who is over all and through all and in all" (Eph 4:1-6). An even clearer call to live in fraternal love and unity can be found in Jesus' prayer as the high priest (cf. John $17: 22-23)$.

The faithful who are joined to the Church through Baptism live by the supernatural hope of attaining the glory of heaven. Hope unites them in their common pursuit of the Father. The Second Vatican Council particularly emphasizes the importance of witnessing to the faith: "reborn as sons of God they must confess before men the faith which they have received from God through the Church." 23 As has already been stated, enlightenment is the fruit of Baptism: "Christ will give you light" (Eph 5:14; cf. Heb 6:4; 10:32). Having left the darkness behind, the baptized should live in the light: "For you were once darkness, but now you are light in the Lord. Live as children of light" (Eph 5:8).

23 Second Vatican Council, Dogmatic Constitution on the Church Lumen Gentium, 11. Pope Francis emphasizes the need to give witness to one's faith, which arises from baptism: "Let us remember that through baptism we also became members of His Body, which is the Church, and partakers of His mission in the world" (cf. Catechism of the Catholic Church, 1213). Therefore, united with Christ and our brothers, we work together in the community of the Church, each according to the call that he has received from God to renew human hearts and change the world." Franciszek, Katecheza Fundament życia chrześcijańskiego [04.11.2018]. Cf.idem, Katecheza Wychowanie chrześcijańskiejest prawem dzieci [05.16.2018]. 
This life in the light is manifested in the public confession of faith that Jesus desires: "Everyone who acknowledges me before others I will acknowledge before my heavenly Father" (Mt 10:32). This personal confession is made possible because of the grace of Baptism; it is a profession of faith that one receives from God through the Church and, therefore, is also the confession of the universal Church who professes the Credo every day "in deed and truth" (1 John 3:18). ${ }^{24}$

Baptism ushers man both individually and socially onto the path Theology of moral perfection. As the sacrament during which God bestows His gifts on man in a particular way, Baptism calls him to assume particular moral attitudes and actions that express his perfection. The entire range of obligations that Baptism places on man flow from the same nature of the gifts that this sacrament imparts. The gift of new life is a call to unceasingly grow in perfection. The gift of being a child of God obliges man to assume a trusting and obedient attitude of a child. Being incorporated into the ecclesial community through Baptism means being responsible for the community of the Church and for being creatively present in different natural communities. All of this should be enlivened with gratitude and joy, which are the appropriate attitudes of someone who has been given a priceless gift. The pursuit of perfection that results from Baptism gives Christian morality a specific character and is not the result of man's autonomous desire, but rather the natural response to having received God's gift.

\section{Bibliography:}

1. Catechism of the Catholic Church. Poznan 1994.

2. Code of Canon Law. Poznań 1984.

3. Franciszek. Katecheza Chrzest daje sitę do walki [04.25.2018].

4. Franciszek. Katecheza Dzieci i znak krzyża [04.18.2018].

5. Franciszek. Katecheza Fundament życia chrześcijańskiego [04.11.2018].

6. Franciszek. Katecheza Wychowanie chrześcijańskie jest prawem dzieci [05.16.2018].

7. Franciszek. Katecheza Wyrzeczenie się szatana $i$ wyznanie wiary [05.02.2018].

8. Franciszek. Katecheza Znamię przynależności na zawsze [05.09.2018].

9. Hadryś, J. "Udział ochrzczonych w kapłańskim, prorockim i królewskim posłannictwie Chrystusa." Teologia i Moralność 10(2015), no. 1: 27-43.

$24 \quad$ Cf. Jan Paweł II, Katecheza Chrzest w Kościele-wspólnocie kapłańskiej i sakramentalnej [03.25.1992], 8. 
10. International Theological Commission. The Reciprocity between Faith and Sacraments in the Sacramental Economy (2020).

11. Jan Paweł II. Katecheza Chrzest w Kościele - wspólnocie kapłańskiej i sakramentalnej [03.25.1992].

12. Jan Paweł. Katecheza Powołanie świeckich do świętości [11.24.1993].

13. John Paul II. Post-Synodal Apostolic Adhortation Christifideles Laici.

14. Niemira, A. "Moralny wymiar sakramentu chrztu w świetle encykliki Lumen fidei papieża Franciszka." Teologia i Człowiek 39(2017), no. 3: 11-23.

15. Olczyk, A. “Chrzest.” In: Jan Paweł II. Encyklopedia nauczania moralnego. Edited by J. Nagórny, K. Jeżyna. Radom 2005, 104-107.

Moral Theology
16. Ratzinger, J. "Chrzest jako początek i drogowskaz życia chrześcijańskiego." In: J. Ratzinger. Opera omnia. Volume 8. Part. 2: Kościót - znak wśród narodów. Pisma eklezjologiczne i ekumeniczne. Edited by K. Góźdź, M. Górecka. Lublin 2013, 1231-1234.

17. Second Vatican Council. Dogmatic Constitution on the Church Lumen Gentium [Vatican City 11.21.1964].

18. Wasiutyńska, K. "Chrzest jako pierwotna konsekracja. U źródeł powszechnego powołania chrześcijan do świętości." Teologia i Moralność 10(2015), no. 1: 7-25.

19. Zadykowicz, T. "Chrystopraksyzm doktryny chrzcielnej." Teologia i Cztowiek 3(2016): 55-76. 